\title{
Candida tartarivorans sp. nov., an anamorphic ascomycetous yeast with the capacity to degrade $L(+)$ - and meso-tartaric acid
}

\author{
Álvaro Fonseca, ${ }^{1}$ Jack W. Fell, ${ }^{2}$ Cletus P. Kurtzman ${ }^{3}$ \\ and Isabel Spencer-Martins ${ }^{1}$
}

Author for correspondence: Álvaro Fonseca. Tel: +351 1 2954464. Fax: + 35112948530.

e-mail:amrf@mail.fct.unl.pt

\footnotetext{
1 Biotechnology Unit, Faculty of Sciences \& Technology/New University of Lisbon, 2825-114 Caparica, Portugal

2 RSMAS, University of Miami, FL, USA

3 Microbial Properties Research Unit, National Center for Agricultural Utilization Research, ARS/USDA, Peoria, IL, USA
}

\begin{abstract}
An undescribed anamorphic yeast species of ascomycetous affinity, for which the name Candida tartarivorans is proposed, was isolated from dried wine lees in Portugal using a selective medium with $\mathrm{L}(+)$-tartaric acid as the sole source of carbon and energy. The single isolate (IGC 4854') showed the following characteristics: sympodial holoblastic conidiogenesis, absence of asci with ascospores, a negative colour reaction with Diazonium Blue $B$, production of elaborate pseudomycelium and ability to grow with inositol as sole source of carbon. Analysis of the physiological data pointed to a close relationship with other inositol-assimilating taxa, namely the genera Arxula, Stephanoascus, Sympodiomyces, Zygoascus and selected Candida species. Comparative analysis of the D1/D2 variable domain of the 26S rRNA gene of all available sequences for ascomycetous yeasts showed that strain IGC $4854^{\top}$ did not match with any other species in the database. The closest relative was Candida auringiensis Santa Maria, but the two species differed in 24 nucleotide positions. A description of the new species is given.
\end{abstract}

Keywords: yeast, taxonomy, Candida, tartaric acid, rDNA sequencing

\section{INTRODUCTION}

The microbial metabolism of tartaric acid, one of the major organic acids in grapes and wines, has received little attention when compared to the structurally similar malic acid, which is also present in grapes and other plant material (Dupuy, 1960; la Rivière, 1958). Studies on the utilization of tartaric acid by yeasts have been pursued in recent years (Fonseca, 1995). We found that the capacity to degrade tartaric acid, and other related aldaric acids, occurs mainly in yeasts of basidiomycetous affinity and very rarely among ascomycetous yeasts (Fonseca, 1992, 1995). The only ascomycetous species that showed the ability to assimilate tartaric acid were Candida bertae, Candida paludigena and Stephanoascus smithiae, which appear to be closely related based on phenotypic (Fonseca, 1992; Giménez-Jurado et al., 1994) and genotypic (Kurtzman \& Robnett, 1995, 1997, 1998) characteristics. In the course of an isolation programme of yeasts from various natural sources in Portugal, using

The GenBank accession number for the partial sequence (D1/D2 domain) of the 26S rRNA gene of IGC $4854^{\top}$ is AF105335. selective media with $\mathrm{L}(+)$-tartaric acid (Fonseca, 1992), we isolated a strain of ascomycetous affinity from dried wine lees, which could not be identified as any previously described species according to morphological and physiological characteristics (Barnett et al., 1990; Kurtzman \& Fell, 1998). Determination of the nucleotide sequence of the D1/D2 variable domain of the 26S (large subunit) rRNA gene for this strain and comparison with a database of sequences from all currently recognized ascomycetous yeasts confirmed the recognition of a new species, Candida tartarivorans Fonseca et al. sp. nov., as described below.

\section{METHODS}

Isolation. The isolation method followed Giménez-Jurado \& van Uden (1989). Samples of dried wine lees were enriched in a liquid mineral medium with vitamins (van Uden, 1967) containing $0.5 \%(\mathrm{w} / \mathrm{v}) \mathrm{L}(+)$-tartaric acid as the sole source of carbon and energy. To discourage bacterial growth, the $\mathrm{pH}$ was adjusted to $3 \cdot 8$ with $10 \mathrm{M} \mathrm{HCl}$. Aliquots were taken daily from the liquid media and plated on solid media with the same composition. Isolated yeast colonies were transferred to YM plates $(1 \%, \mathrm{w} / \mathrm{v}$, glucose; $0.5 \%$ peptone; $0.3 \%$ yeast extract; $0.3 \%$ malt extract; $2 \%$ agar) to check 
their purity. The strain was maintained on YM slants at $4{ }^{\circ} \mathrm{C}$.

Characterization of the strain. The identification methods, including determination of molar content of $\mathrm{G}+\mathrm{C}$ in $\mathrm{nDNA}$ (thermal denaturation method; four determinations; reference: nDNA of Candida parapsilosis CBS $604-\mathrm{G}+\mathrm{C}=$ $40.5 \mathrm{~mol} \%$ ), followed Giménez-Jurado et al. (1990). In addition to assessing the utilization of standard carbon compounds in liquid media, several aldaric acids (Fonseca, 1992) and aromatic compounds (Sampaio, 1994) were tested using the techniques of Yarrow (1998). The only difference resided in the concentrations used for the aromatic compounds $-0 \cdot 1 \%(\mathrm{w} / \mathrm{v})$ - since some of them can be toxic for yeasts. DNA isolation and PCR amplification of the D1/D2 variable region of the $26 \mathrm{~S}$ rDNA were performed using standard protocols (Kurtzman \& Robnett, 1998). The sequence from the D1/D2 600-650 bp region at the 5' end of the 26S rDNA was obtained with a LI-COR Automated Sequencer using standard protocols (Fell et al., 1995). Cycle sequencing employed forward primer 5'-GCA TAT CAA TAA GCG GAG GAA AAG and reverse primer 5'-GGT CCG TGT TTC AAG ACG. Phylogenetic trees were computed from aligned nucleotide sequences according to the procedures described by Kurtzman \& Robnett (1997). All reference sequences are available at GenBank (see accession nos in Kurtzman \& Robnett, 1997, 1998).

\section{RESULTS}

\section{Latin diagnosis of Candida tartarivorans Fonseca, Fell, Kurtzman \& Spencer-Martins sp. nov.}

In medio liquido cum dextroso et peptono et extracto levedinis et extracto malti post 3 dies ad $25^{\circ} \mathrm{C}$ cellulae sunt ellipsoideae ad cylindratae pro maxima partes irregulares $(2 \cdot 0-3 \cdot 5 \times 3 \cdot 0-7 \cdot 0 \mu \mathrm{m})$, singulae vel binae. Reproductio vegetativa per holoblastice gemmationem. Pellicula ascendente et sedimentum adest. Cultura in agaro cum dextroso et peptono et extracto levedinis et extracto malti post 7 dies ad $25^{\circ} \mathrm{C}$, albido cremea, glabra vel rugosa, nitida aut non nitida, butyracea, margine fimbriata cum mycelium. In agaro farina Zea maydis confecto post 7 dies ad $25^{\circ} \mathrm{C}$, pseudomycelium cum blastoconidia ovata vel pyriforma formatur. Glucosum, galactosum, saccharum (lente), maltosum (lente), trehalosum (lente), melibiosum (lente), raffinosum (lente) fermentantur, at non cellobiosum, lactosum, melezitosum nec inulinum. Glucosum, galactosum, L-sorbosum, D-glucosaminum, D-ribosum (lente), D-xylosum, L-arabinosum, D-arabinosum (lente), saccharum, maltosum, trehalosum, methyl $\alpha-D-$ glucosidum (lente), cellobiosum (lente), salicinum (lente), melibiosum, lactosum, raffinosum, melezitosum (lente), amylum, ethanolum (lente, exigue), glycerolum, erythritolum, ribitolum, xylitolum, D-glucitolum, D-mannitolum, galactitolum, inositolum, glucono-lactonum (lente), acidum D-gluconicum, acidum D-glucuronicum, acidum succinicum, acidum citricum (lente), acidum L-malicum et acidum L-tartaricum assimilantur at non L-rhamnosum, inulinum, acidum DLlacticum, nec methanolum. Assimilatio L-lysini (lente), ethylamini et cadaverini (lente) ad non kallii nitratis, sodii nitrosi, creatini nec creatinini. Vitamina externa ad

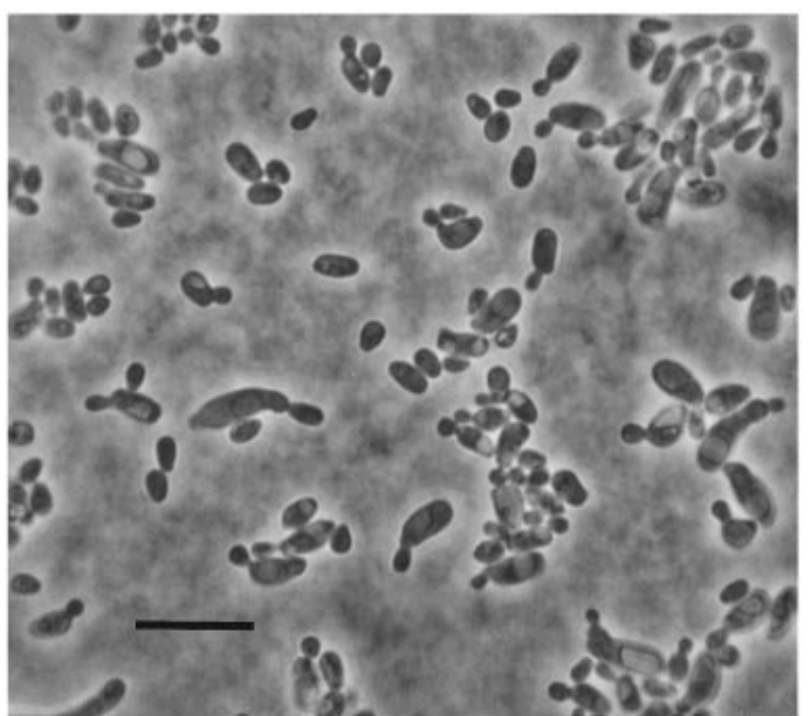

Fig. 1. Cells of Candida tartarivorans (IGC $4854^{\top}$ ) after $2 \mathrm{~d}$ in YM broth at $25^{\circ} \mathrm{C}$. Phase-contrast. Bar, $10 \mu \mathrm{m}$.

crescentiam necessaria sunt. Maxima temperatura crescentiae: $43-44{ }^{\circ} \mathrm{C}$. Materia amyloidea non formantur. Ureum non finditur. Proportio molaris guanini plus cytosini in acido deoxyribonucleico: $40 \cdot 1 \pm 0 \cdot 4$ per centum. Typus: IGC $4854^{\mathrm{T}}$, ex 'wine lees' in Lusitania isolatus, exsiccatus et vivus in collectione zymotica lusitanica et vivus in collectione zymotica Delphis Batavorum (CBS $7955^{\mathrm{T}}$ ) praeservatus.

\section{Description of Candida tartarivorans Fonseca, Fell, Kurtzman \& Spencer-Martins sp. nov.}

Candida tartarivorans (tar.tar.i.vor'ans. M.L. adj. tartarivorans tartaric-acid-consuming, due to the ability of this yeast to utilize tartaric acid as sole source of carbon and energy).

Growth in YM broth. After $3 \mathrm{~d}$ at $25^{\circ} \mathrm{C}$, the cells were ellipsoidal to short cylindrical $(2 \cdot 0-3 \cdot 5 \times 3 \cdot 0-7 \cdot 0 \mu \mathrm{m})$ and occurred singly, in pairs or in short chains (Fig. 1). Some irregular shapes and a few elongated (up to $10 \mu \mathrm{m})$, slightly curved cells were also present. Sympodial holoblastic conidiogenesis resulted in ovoid to obclavate conidia (approx. $2 \times 3 \mu \mathrm{m}$ ) that arose on more or less pronounced protuberances.

Growth on YM agar. After $7 \mathrm{~d}$ at $25^{\circ} \mathrm{C}$, the colonies were white to cream-coloured and butyrous. Two morphotypes became apparent after repeated subculturing: one had a somewhat rough and dull surface and the other was smooth and slightly glistening. The margin was fringed with mycelium developing into the agar in both colony types.

Dalmau plate culture on corn meal agar. After 1 week at $25^{\circ} \mathrm{C}$, there was abundant formation of well-developed pseudomycelium (both aerobically and anaerobi- 
Table 1. Physiological characteristics of Candida tartarivorans sp. nov.

Compounds are ordered according to Barnett et al. (1990). Incubation of assimilation tests was performed with continuous agitation. Test results: + , positive (strong growth); $+\mathrm{D}$, delayed (positive result after 1 week or longer); w, weak growth; wD, weak and delayed; -, negative (no growth).

\begin{tabular}{|c|c|}
\hline Compound & Result \\
\hline \multicolumn{2}{|c|}{ Fermentation of carbohydrates } \\
\hline D-Glucose & + \\
\hline D-Galactose & + \\
\hline Maltose & $+\mathrm{D}$ \\
\hline Sucrose & $+\mathrm{D}$ \\
\hline Trehalose & $+\mathrm{D}$ \\
\hline Melibiose & $+\mathrm{D}$ \\
\hline Lactose & - \\
\hline Cellobiose & - \\
\hline Melezitose & - \\
\hline Raffinose & $+\mathrm{D}$ \\
\hline Inulin & - \\
\hline \multicolumn{2}{|c|}{ Assimilation of carbon compounds } \\
\hline D-Glucose & + \\
\hline D-Galactose & + \\
\hline L-Sorbose & + \\
\hline D-Glucosamine & + \\
\hline D-Ribose & $+\mathrm{D}$ \\
\hline D-Xylose & + \\
\hline L-Arabinose & + \\
\hline D-Arabinose & $+\mathrm{D}$ \\
\hline L-Rhamnose & - \\
\hline Sucrose & + \\
\hline Maltose & + \\
\hline$\alpha, \alpha$-Trehalose & + \\
\hline Methyl $\alpha$-glucoside & $+\mathrm{D}$ \\
\hline Cellobiose & $+\mathrm{D}$ \\
\hline Salicin & $+\mathrm{D}$ \\
\hline Melibiose & + \\
\hline Lactose & + \\
\hline Raffinose & + \\
\hline Melezitose & $+\mathrm{D}$ \\
\hline Inulin & - \\
\hline Soluble starch & + \\
\hline Glycerol & + \\
\hline Erythritol & + \\
\hline Ribitol & + \\
\hline Xylitol & + \\
\hline D-Glucitol & + \\
\hline D-Mannitol & + \\
\hline Galactitol & + \\
\hline Inositol & + \\
\hline Glucono- $\delta$-lactone & $+\mathrm{D}$ \\
\hline D-Gluconate & w \\
\hline D-Glucuronate & + \\
\hline D,L-Lactic acid & - \\
\hline Succinic acid & $+\mathrm{D}$ \\
\hline Citric acid & WD \\
\hline
\end{tabular}

\begin{tabular}{|lc|}
\hline Compound & Result \\
\hline Assimilation of carbon compounds & \\
Methanol & - \\
Ethanol & WD \\
Aldaric acids & \\
L-Malic acid & + \\
L-Tartaric acid & + \\
D-Tartaric acid & - \\
meso-Tartaric acid & + D \\
Saccharic acid & - \\
Mucic acid & - \\
Aromatic compounds & \\
Protocatechuic acid & - \\
Vanillic acid & - \\
Veratric acid & - \\
Ferulic acid & - \\
p-Hydroxybenzoic acid & - \\
m-Hydroxybenzoic acid & - \\
Gallic acid & - \\
Salicylic acid & - \\
Gentisic acid & - \\
Catechol & - \\
Phenol & - \\
Assimilation of nitrogen compounds & - \\
Nitrate & - \\
Nitrite & - \\
L-Lysine & - \\
Ethylamine & - \\
Cadaverine & - \\
Creatine & - \\
Creatinine & - \\
D-Glucosamine & - \\
& - \\
\hline
\end{tabular}

cally). Obclavate blastoconidia formed abundantly at the junctures of pseudohyphal cells, as well as terminally. In 1-month-old cultures true hyphae were observed.

Sexual reproduction. Asci were not observed on the media tested [YM (yeast extract-malt extract agar), ME (5\% malt extract agar), CMA (corn meal agar), PDA (potato-dextrose agar)], incubated at $25^{\circ} \mathrm{C}$ and checked periodically during a 3 week period.

Physiological characteristics. See Table 1 for a summary.

Other characteristics. Growth in vitamin-free medium, negative; maximum growth temperature, $43-44^{\circ} \mathrm{C}$; formation of extracellular starch-like compounds, negative; arbutin splitting, positive (after 1 week); urea hydrolysis, negative; colour reaction with Diazonium Blue B, negative; growth in the presence of $0.1 \%(\mathrm{w} / \mathrm{v})$ cycloheximide, positive; growth on $50 \%$ $(\mathrm{w} / \mathrm{v})$ glucose-yeast extract agar, absent; growth in $10 \%(\mathrm{w} / \mathrm{v}) \mathrm{NaCl} / 5 \%(\mathrm{w} / \mathrm{v})$ glucose, absent; $\mathrm{G}+\mathrm{C}$ content of nuclear DNA $\left(T_{\mathrm{m}}\right), 40 \cdot 1 \pm 0 \cdot 4 \mathrm{~mol} \%$ (mean of four determinations); $26 \mathrm{~S}$ rDNA partial (D1/D2 


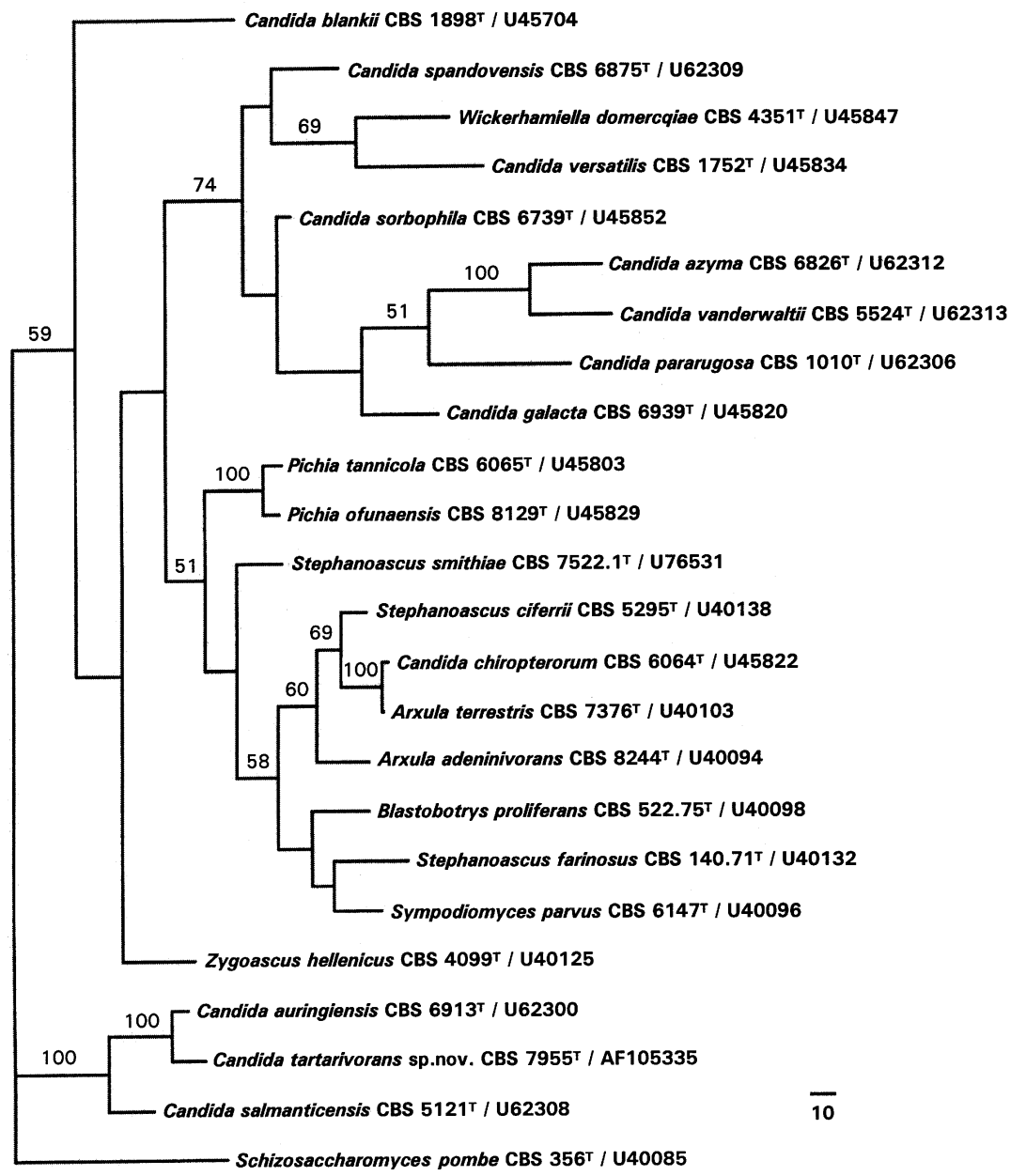

Fig. 2. Phylogenetic tree derived from maximum-parsimony analysis using PAUP 4.0 (Sinauer Associates, Inc., Sunderland, MA, USA) for selected ascomycetous species using Schizosaccharomyces pombe as the outgroup. Species included were nearest neighbours from a previous all-ascomycete search by neighbour-joining. The phylogram was calculated from nucleotide divergence in the D1/D2 region of the 26S rRNA gene. Branch lengths are proportional to the number of nucleotide differences (insert bar) and the numbers given on branches are the frequencies ( $>50 \%$ ) with which a given branch appeared in 1000 bootstrap replications.

domain) sequencing, Fig. 2 depicts a phylogenetic tree resulting from the comparison of the sequence obtained for strain IGC $4854^{\mathrm{T}}$ with selected ascomycetous species.

Origin of the strain studied. The type strain IGC $4854^{\mathrm{T}}$ was isolated in April 1991 from dried wine lees piled in a warehouse for subsequent distilling at Runa (Torres Vedras region, a wine-producing area of Portugal). The strain was deposited in the Portuguese Yeast Culture Collection (Monte de Caparica, Portugal), the Yeast Division of the Centraalbureau voor Schimmelcultures (Delft, The Netherlands), CBS $7955^{\mathrm{T}}$, and in the ARS Culture Collection (Peoria, IL, USA), NRRL $\mathrm{Y}-27291^{\mathrm{T}}$, as living and as lyophilized type material.

\section{DISCUSSION}

Strain IGC $4854^{\mathrm{T}}$ showed the following characteristics: absence of sexual reproduction; negative results for both the urease and Diazonium Blue B tests; and absence of extracellular starch-like compounds. Based on these characteristics it was assigned to the genus Candida Berkhout (Meyer et al., 1998). Although the presence of sympodial conidiogenesis on denticles suggested a possible inclusion in the genera
Arxula, Blastobotrys or Sympodiomyces, the overall characteristics of the strain did not comply entirely with any of those generic diagnoses (Kurtzman \& Fell, 1998). Moreover, based on physiological characteristics, IGC $4854^{\mathrm{T}}$ did not fit the description of any of the currently accepted Candida species or of any other ascomycetous yeast species (Barnett, 1996; Kurtzman \& Fell, 1998). Use of the available keys for yeast identification in Kurtzman \& Fell (1998) and the identification program of Barnett (1996) yielded the species listed in Table 2, which had physiological profiles close to our strain. Table 2 also contains selected characteristics that allow discrimination of the species listed. Conspecificity with Blastobotrys proliferans can be ruled out due to the peculiar morphological characteristics of the latter species (de Hoog \& Smith, 1998), as well as from the considerable differences in D1/D2 nucleotide sequences (Fig. 2). A possible relationship between these species and others that share the ability to assimilate inositol had been previously suggested based on the comparative analysis of phenotypic characteristics (Fonseca, 1992; Giménez-Jurado et al., 1994). Recent molecular studies based on the analysis of partial sequences of the $26 \mathrm{~S}$ rRNA gene established a close phylogenetic relationship between the genera Arxula, Blastobotrys, 
Table 2. Selected characteristics of species phenotypically similar to Candida tartarivorans

Glucose fermentation, FGlu; assimilation of: L- rhamnose (Rha), sucrose (Suc), melibiose (Mel), melezitose (Mlz), erythritol (Ery), inositol (Ino), L-tartaric acid (L-Tar), nitrate (Nit), D-glucosamine (nitrogen source) [Glm(N)]; growth at $42{ }^{\circ} \mathrm{C}\left(42^{\circ} \mathrm{C}\right)$. Results: +, positive; - , negative; v, variable; ND, not determined.

\begin{tabular}{|c|c|c|c|c|c|c|c|c|c|c|c|c|}
\hline \multirow[t]{2}{*}{ Species } & \multicolumn{11}{|c|}{ Selected physiological characteristics } & \multirow{2}{*}{$\begin{array}{c}\mathrm{G}+\mathrm{C} \\
(\mathrm{mol} \%)^{*}\end{array}$} \\
\hline & FGlu & Rha & Suc & Mel & Mlz & Ery & Ino & L-Tar & Nit & $\operatorname{GIm}(\mathbf{N})$ & $42{ }^{\circ} \mathrm{C}$ & \\
\hline Candida tartarivorans & + & - & + & + & + & + & + & + & - & + & + & $40 \%$ \\
\hline Candida auringiensis & + & - & - & - & - & + & + & - & - & + & - & 40 \\
\hline Candida blankii & $\mathrm{V}$ & + & + & - & + & + & + & - & - & - & - & $54-56$ \\
\hline Arxula adeninivorans & $\mathrm{V}$ & - & + & + & + & + & + & - & + & + & + & ND \\
\hline Blastobotrys proliferans & + & $\mathrm{V}$ & + & + & $\mathrm{V}$ & + & + & ND & - & ND & ND & ND \\
\hline Zygoascus hellenicus & $\mathrm{V}$ & + & + & - & $\mathrm{V}$ & - & + & - & - & + & - & $43-45$ \\
\hline
\end{tabular}

* Mol \% G + C in nDNA, determined by the thermal denaturation method $\left(T_{\mathrm{m}}\right)$. Values are taken from Kurtzman \& Fell (1998), except $\ddagger$, determined in the present work. ND, Not determined.

Stephanoascus, Sympodiomyces, Zygoascus and some Candida species (Kurtzman \& Robnett, 1995, 1997, 1998).

The phylogenetic tree depicted in Fig. 2 points to a close relationship of $C$. tartarivorans sp. nov. with Candida auringiensis in a clade that also contains Candida salmanticensis, which in turn appears to be only distantly related to the Stephanoascus clade. Conspecificity of $C$. tartarivorans sp. nov. and $C$. auringiensis, the nearest known relative, can be ruled out since we found differences in the respective sequences at 24 nucleotide positions. Salient physiological differences between the two species are given in Table 2. Both yeasts originated from man-made environments (wine making and olive oil extraction, respectively) in the Iberian peninsula and share the ability to utilize inositol, erythritol and D-glucosamine (as carbon and nitrogen source), a combination of characters found only in some members of the above-mentioned group of genera. Cells of $C$. auringiensis also display the protuberances found in $C$. tartarivorans sp. nov. resulting from the sympodial type of conidiogenesis that occurs in these yeasts. Additional studies are necessary to further investigate possible correlations in the morphology, physiology and phylogeny in this group of taxa.

There has been a tendency in modern yeast taxonomy to avoid describing anamorphic species based on the phenotypic characterization of a single strain. However, the recent availability of species-diagnostic sequence databases composed of all currently accepted taxa offers the opportunity for rapid, unambiguous identification of new isolates, thus avoiding taxonomic redundancies (Fell et al., 1995; Kurtzman \& Robnett, 1997, 1998). Therefore, in view of the molecular data determined in this study, we have described a novel species, Candida tartarivorans, to accommodate strain IGC $4854^{\mathrm{T}}$, as a contribution to improving the systematics of the above-mentioned group of species.
Moreover, the probability of finding a teleomorph for the newly described species will certainly increase if more strains are discovered. Attempts shall be made to obtain additional isolates from the same source material. Physiological and biochemical aspects of tartaric acid utilization by this strain were also studied and will be the subject of a future report.

\section{ACKNOWLEDGEMENTS}

Work by A. F. at the University of Miami (J. W. Fell) was supported in part by a grant from 'Fundação LusoAmericana para o Desenvolvimento' (Portugal). Research by J.W.F. was supported by the National Science Foundation/Ocean Sciences Division (USA).

\section{REFERENCES}

Barnett, J. A. (1996). Yeast Identification PC Program: version 4. ISBN 0951314882.

Barnett, J. A., Paine, R. W. \& Yarrow, D. (1990). Yeasts: Characteristics and Identification, 2nd edn. Cambridge: Cambridge University Press.

Dupuy, P. (1960). Le métabolisme de l'acide tartrique. Ann Technol Agric 2, 139-184.

Fell, J. W., Boekhout, T. \& Freshwater, D. W. (1995). The role of nucleotide analysis in the systematics of the yeast genera Cryptococcus and Rhodotorula. Stud Mycol 38, 129-146.

Fonseca, A. (1992). Utilization of tartaric acid and related compounds by yeasts: taxonomic implications. Can J Microbiol 38, 1242-1251.

Fonseca, A. (1995). Utilization of tartaric acid by yeasts: taxonomic, physiological and biochemical aspects. PhD thesis, New University of Lisbon (in Portuguese).

Giménez-Jurado, G. \& van Uden, N. (1989). Leucosporidium fellii sp. nov., a basidiomycetous yeast that degrades $\mathrm{L}(+)$-tartaric acid. Antonie Leeuwenhoek 57, 133-141.

Giménez-Jurado, G., Plácido, T., Cidadão, A. J., Cabeça-Silva, C., Fonseca, E., Roeijmans, H. J., van Eijk, G. W. \& van Uden, N. (1990). Kurtzmanomyces tardus sp. nov., a new anamorphic 
yeast species of basidiomycetous affinity. Antonie Leeuwenhoek 58, 129-135.

Giménez-Jurado, G., Cidadão, A. J. \& Beijn-van der Waaij, A. (1994). A novel heterothallic ascomycetous yeast species: Stephanoascus smithiae, teleomorph of Candida edax. Syst Appl Microbiol 17, 237-246.

de Hoog, G. S. \& Smith, M. Th. (1998). Blastobotrys von Klopotek. In The Yeasts, a Taxonomic Study, 4th edn, pp. 443-448. Edited by C. P. Kurtzman \& J. W. Fell. Amsterdam: Elsevier.

Kurtzman, C. P. \& Fell, J. W. (editors) (1998). The Yeasts, a Taxonomic Study, 4th edn. Amsterdam: Elsevier.

Kurtzman, C. P. \& Robnett, C. J. (1995). Molecular relationships among hyphal ascomycetous yeasts and yeastlike taxa. Can $J$ Bot 73 (suppl. 1), S824-S830.

Kurtzman, C. P. \& Robnett, C. J. (1997). Identification of clinically important ascomycetous yeasts based on nucleotide divergence in the $5^{\prime}$ end of the large-subunit (26S) ribosomal DNA gene. $J$ Clin Microbiol 35, 1216-1223.

Kurtzman, C. P. \& Robnett, C. J. (1998). Identification and phylogeny of ascomycetous yeasts from analysis of nuclear large subunit (26S) ribosomal DNA partial sequences. Antonie Leeuwenhoek 73, 331-371.

Meyer, S. A., Payne, R. W. \& Yarrow, D. (1998). Candida Berkhout. In The Yeasts, a Taxonomic Study, 4th edn, pp. 454-573. Edited by C. P. Kurtzman \& J. W. Fell. Amsterdam: Elsevier.

la Rivière, J. W. M. (1958). On the microbial metabolism of the tartaric acid isomers. PhD thesis, Technische Hogenschool, Delft, The Netherlands.

Sampaio, J. P. (1994). Utilization of low molecular weight ligninrelated aromatic compounds for the selective isolation of yeasts: Rhodotorula vanillica, a new basidiomycetous yeast species. Syst Appl Microbiol 17, 613-619.

van Uden, N. (1967). Transport-limited fermentation and growth of Saccharomyces cerevisiae and its competitive inhibition. Arch Mikrobiol 58, 155-168.

Yarrow, D. (1998). Methods for the isolation, maintenance and identification of yeasts. In The Yeasts, a Taxonomic Study, 4th edn, pp. 77-100. Edited by C. P. Kurtzman \& J. W. Fell. Amsterdam: Elsevier. 